\title{
COMPARISON OF ANTIGENS IN THE OVARY, OVIDUCT AND UTERUS OF THE RABBIT AND OTHER MAMMALIAN SPECIES
}

\author{
A. G. SACCO* AND C. A. SHIVERS \\ Department of Zoology, University of Tennessee, \\ Knoxville, Tennessee 37916, U.S.A.
}

(Received 17th Fanuary 1972)

\begin{abstract}
Summary. Sheep antisera prepared against saline extracts of rabbit (Californian) ovary, oviduct and uterus were used to detect the presence of homologous antigens in the ovaries and reproductive tracts of the Dutch rabbit, New Zealand White (NZW) rabbit, guinea-pig, hamster, mouse and rat. Absorption of each antiserum with Californian rabbit plasma, kidney and spleen and the reaction of the absorbed antisera in immunodiffusion plates against the homologous antigen from each species produced the following results: (1) absorbed anti-ovary serum formed precipitin bands with two antigens in the ovaries of each of the breeds of rabbit while forming no bands when allowed to react with the ovaries of the other mammals tested; (2) absorbed anti-oviduct serum formed bands with six antigens in the oviducts of each of the rabbit breeds, two antigens in the mouse oviduct, one in the rat oviduct and formed no bands with the oviducal material from the guinea-pig and hamster; (3) absorbed anti-uterus serum formed bands with two antigens in the uterus of the NZW rabbit and one band with the uterine material from the Dutch rabbit and other species. None of the three absorbed antisera reacted with the sixteen non-reproductive tissues or testis preparations from each of the different species. These results demonstrated that antigens present in reproductive tissues of the Californian rabbit were also present in several other mammalian species.
\end{abstract}

\section{INTRODUCTION}

Immunological analysis revealed that the ovary and reproductive tract of the female (Californian) rabbit contained antigens not present in other tissues (Sacco \& Shivers, 1973a). The two ovarian-specific antigens were localized in the zona pellucida, theca interna and atretic follicles; the six oviducal antigens, in the mucosal lining; and the two uterine antigens, in the endometrial stroma and cervical lamina propria (Sacco \& Shivers, 1973b). The tissue-specificity of these antigens and their localization within specific areas of the reproductive

* Present address: The Institute for Gancer Research, 7701 Burholme Avenue, Philadelphia, Pa. 19111, U.S.A. 
tissues suggests the possibility of the existence of similar antigens in other mammals. The present investigation was undertaken in an attempt to detect reproductive tissue-specific antigens in the Dutch and New Zealand White (NZW) rabbit, guinea-pig, hamster, mouse and rat with antisera prepared against reproductive tissues of the female (Californian) rabbit.

\section{MATERIALS AND METHODS}

\section{Preparation of antisera}

Sheep antisera were produced against saline extracts of rabbit (Californian) ovary, oviduct and uterus and absorbed, following procedures described by Sacco \& Shivers (1973a). Immunodiffusion analyses demonstrated that absorption of each antiserum with rabbit (Californian) plasma, kidney and spleen $(\mathrm{p}, \mathrm{k}, \mathrm{s})$ rendered the antiserum specific to reproductive tissue.

\section{Preparation of tissue homogenates for immunodiffusion plates}

Tissues were obtained from mature rabbits (Californian, Dutch, NZW), guinea-pigs (American), hamsters (Golden Syrian), mice (random-bred albino) and rats (random-bred albino). The non-rabbit species used were in various stages of the oestrous cycle. All tissues were freed of adhering connective tissue and washed in cold $\left(4^{\circ} \mathrm{C}\right)$ phosphate-buffered saline (PBS, 0.1 м- $\mathrm{PO}_{4}, 0.85 \%$ $\mathrm{NaCl}, \mathrm{pH} 7 \cdot 3$ ). For each species, identical tissues were pooled, homogenized in cold PBS to a final concentration of $25 \%(\mathrm{w} / \mathrm{v})$, centrifuged for $10 \mathrm{~min}$ at $2500 \mathrm{~g}$ to remove tissue débris and the supernatants used in immunodiffusion plates. Plasma, serum and red blood cell (RBC) preparations obtained as previously described (Sacco \& Shivers, 1973a) were also tested.

\section{Detection of antigens}

Because of the large numbers of tissues examined and the small quantity of material available for some tissues, a modification of the immunodiffusion technique (see Mansi, 1958) was used. Microdiffusion plates were prepared by pouring $1.5 \mathrm{ml}$ of a $1 \%$ solution of agarose in distilled water or PBS on to $1 \times 3$ in. glass slides. The gel was cut with a template to give one central well and six smaller peripheral wells $(9 \mathrm{~mm}$ between wells). Liquid levels in wells were maintained by fluid addition, giving a total volume of 0.08 to $0.12 \mathrm{ml}$ per well. Plates were allowed to develop for 48 to $72 \mathrm{hr}$ at room temperature (20 to $22^{\circ} \mathrm{C}$ ).

\section{RESULTS}

\section{Unabsorbed antisera}

Antisera produced in sheep against the uterus of the Californian rabbit were tested in immunodiffusion plates against saline extracts of reproductive and non-reproductive tissues from Californian, Dutch and NZW rabbits and similar tissues from guinea-pigs, hamsters, mice and rats. The number of precipitin bands produced by such tests (shown in Table 1) were interpreted as indicating the degree of cross-reactivity (common antigens) between the tissue 
being tested and the uterus of the Californian rabbit. A high degree of crossreactivity was seen between the anti-uterus sera and extracts of reproductive and non-reproductive tissues from the three breeds of rabbit (compare Columns A, B and C in Table 1). A lower degree of cross-reactivity was observed when the antisera were tested against reproductive and non-reproductive tissues from the other mammalian species (compare Columns A to $\mathrm{C}$ with columns $\mathrm{D}$ to $\mathrm{G}$, Table 1).

Table 1. Tissue antigens from various species detected by unabsorbed anti-uterus sera*

\begin{tabular}{|c|c|c|c|c|c|c|c|}
\hline \multirow[b]{2}{*}{ Antigen } & \multicolumn{7}{|c|}{ Species } \\
\hline & $\begin{array}{c}A \\
\substack{\text { Californian } \\
\text { rabbit }}\end{array}$ & $\begin{array}{c}B \\
\text { Dutch } \\
\text { rabbit }\end{array}$ & $\begin{array}{c}C \\
\text { New } \\
\text { Zealand } \\
\text { White } \\
\text { rabbit }\end{array}$ & $\begin{array}{c}D \\
\text { Guinea- } \\
\text { pig }\end{array}$ & $\left|\begin{array}{c}E \\
\text { Hamster }\end{array}\right|$ & $\begin{array}{c}F \\
\text { Mouse }\end{array}$ & $\begin{array}{c}G \\
R a t\end{array}$ \\
\hline $\begin{array}{l}\text { Ovary } \\
\text { Oviduct } \\
\text { Uterus } \\
\text { Adrenal gland } \\
\text { Brain } \\
\text { Duodenum } \\
\text { Fat } \\
\text { Heart } \\
\text { Ileum } \\
\text { Kidney } \\
\text { Liver } \\
\text { Lung } \\
\text { Pancreas } \\
\text { Plasma } \\
\text { Red blood cells } \\
\text { Serum } \\
\text { Skeletal muscle } \\
\text { Spleen } \\
\text { Stomach } \\
\text { Testis }\end{array}$ & $\begin{array}{r}11 \\
12 \\
10 \\
11 \\
3 \\
10 \\
8 \\
9 \\
8 \\
12 \\
10 \\
10 \\
5 \\
13 \\
3 \\
14 \\
5 \\
9 \\
7 \\
8\end{array}$ & $\begin{array}{r}11 \\
12 \\
12 \\
8 \\
5 \\
8 \\
8 \\
10 \\
8 \\
12 \\
8 \\
10 \\
11 \\
16 \\
7 \\
15 \\
3 \\
10 \\
9 \\
11\end{array}$ & $\begin{array}{r}12 \\
10 \\
12 \\
10 \\
4 \\
10 \\
5 \\
11 \\
10 \\
10 \\
9 \\
10 \\
6 \\
15 \\
7 \\
15 \\
5 \\
10 \\
6 \\
9\end{array}$ & $\begin{array}{l}2 \\
0 \\
2 \\
1 \\
0 \\
0 \\
0 \\
1 \\
1 \\
1 \\
1 \\
1 \\
4 \\
1 \\
1 \\
1 \\
2 \\
0 \\
1\end{array}$ & $\begin{array}{l}1 \\
0 \\
3 \\
2 \\
0 \\
1 \\
0 \\
1 \\
1 \\
2 \\
2 \\
2 \\
1 \\
2 \\
0 \\
2 \\
1 \\
1\end{array}$ & $\begin{array}{l}0 \\
0 \\
3 \\
0 \\
0 \\
0 \\
0 \\
0 \\
0 \\
1 \\
0 \\
2 \\
1 \\
0 \\
0 \\
2 \\
0 \\
0\end{array}$ & $\begin{array}{l}0 \\
0 \\
2 \\
2 \\
0 \\
1 \\
0 \\
1 \\
1 \\
1 \\
2 \\
1 \\
1 \\
0 \\
0 \\
2 \\
0 \\
0\end{array}$ \\
\hline
\end{tabular}

Each numeral indicates the maximum number of precipitin bands observed in immunodiffusion plates when the antisera were allowed to react against a particular tissue. Each reaction was tested at least ten times and involved the use of different preparations of reactants.

* Prepared against Californian rabbit uterus.

$(-)=$ Not examined.

To determine whether the low degree of cross-reactivity observed between anti-uterus sera and the non-rabbit tissues was unique to the uterus, unabsorbed antisera against ovary and oviduct were examined. Both these antisera, when allowed to react with the non-rabbit tissues, produced results similar to those observed for the anti-uterus sera, i.e. they expressed a high degree of crossreactivity with the rabbit tissues (Tables 2 and 3, Columns $A$ to $C$ ) and a low degree of cross-reactivity with the non-rabbit tissues (Tables 2 and 3, Columns $D$ to $G)$. Such results indicated that the tissues of the non-rabbit species contained few antigens capable of cross-reacting with antisera prepared against these three rabbit tissues. 


\section{Absorbed antisera}

Since the p-, k- and s-absorbed antisera have been shown to be specific for antigens present only in Californian rabbit reproductive tissue (Sacco \& Shivers, 1973a), such antisera were allowed to react with tissues from other species to determine whether reproductive tissue-specific antigens were also present in these species. The results obtained when such absorbed antisera were allowed to react against the various reproductive tissues are summarized in Table 4.

Table 2. Tissue antigens from various species detected by unabsorbed anti-ovary sera*

\begin{tabular}{|c|c|c|c|c|c|c|c|}
\hline \multirow[b]{2}{*}{ Antigen } & \multicolumn{7}{|c|}{ Species } \\
\hline & $\begin{array}{c}A \\
\begin{array}{c}\text { Califormian } \\
\text { rabbit }\end{array}\end{array}$ & $\begin{array}{c}B \\
\begin{array}{c}\text { Dutch } \\
\text { rabbit }\end{array}\end{array}$ & \begin{tabular}{c}
\multicolumn{1}{c}{$C$} \\
New \\
Zealand \\
White \\
rabbit
\end{tabular} & $\begin{array}{c}D \\
\text { Guinea- } \\
\text { pig }\end{array}$ & $\begin{array}{c}E \\
\text { Hamster }\end{array}$ & $\begin{array}{c}\text { F } \\
\text { Mouse }\end{array}$ & $\begin{array}{r}G \\
R a t\end{array}$ \\
\hline $\begin{array}{l}\text { Plasma } \\
\text { Kidney } \\
\text { Spleen } \\
\text { Lung }\end{array}$ & $\begin{array}{l}15 \\
14 \\
10 \\
13\end{array}$ & $\begin{array}{l}14 \\
12 \\
12 \\
12\end{array}$ & $\begin{array}{l}14 \\
12 \\
12 \\
11\end{array}$ & $\begin{array}{l}2 \\
3 \\
3 \\
2\end{array}$ & $\begin{array}{l}0 \\
2 \\
1 \\
1\end{array}$ & $\begin{array}{l}1 \\
0 \\
1 \\
0\end{array}$ & $\begin{array}{l}0 \\
1 \\
2 \\
1\end{array}$ \\
\hline
\end{tabular}

Each numeral indicates the maximum number of precipitin bands observed in immudodiffusion plates when the antisera were allowed to react against a particular tissue. Each reaction was tested at least ten times and involved the use of different preparations of reactants.

* Prepared against Californian rabbit ovary.

Table 3. Tissue antigens from various species detected by unabsorbed anti-oviduct sera*

\begin{tabular}{|c|c|c|c|c|c|c|c|}
\hline \multirow[b]{2}{*}{ Antigen } & \multicolumn{7}{|c|}{ Species } \\
\hline & 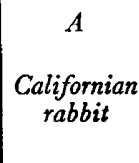 & $\begin{array}{c}B \\
\text { Dutch } \\
\text { rabbit }\end{array}$ & $\begin{array}{c}C \\
\text { New } \\
\text { Zealand } \\
\text { White } \\
\text { rabbit }\end{array}$ & $\begin{array}{c}D \\
\begin{array}{c}\text { Guinea- } \\
\text { pig }\end{array}\end{array}$ & $\begin{array}{c}E \\
\text { Hamster }\end{array}$ & $\begin{array}{c}\text { F } \\
\text { Mouse }\end{array}$ & $\begin{array}{r}G \\
\text { Rat }\end{array}$ \\
\hline $\begin{array}{l}\text { Plasma } \\
\text { Kidney } \\
\text { Spleen } \\
\text { Lung }\end{array}$ & $\begin{array}{l}13 \\
12 \\
10 \\
11\end{array}$ & $\begin{array}{l}11 \\
11 \\
12 \\
13\end{array}$ & $\begin{array}{r}10 \\
11 \\
9 \\
13\end{array}$ & $\begin{array}{l}3 \\
1 \\
0 \\
0\end{array}$ & $\begin{array}{l}0 \\
1 \\
2 \\
2\end{array}$ & $\begin{array}{l}1 \\
0 \\
3 \\
1\end{array}$ & $\begin{array}{l}0 \\
1 \\
2 \\
1\end{array}$ \\
\hline
\end{tabular}

Each numeral indicates the maximum number of precipitin bands observed in immunodiffusion plates when the antisera were allowed to react against a particular tissue. Each reaction was tested at least ten times and involved the use of different preparations of reactants.

* Prepared against Californian rabbit oviduct.

Each absorbed antiserum was allowed to react only against homologous antigens from each of the species (e.g. anti-ovary versus ovary but not versus oviduct or uterus) and consequently no data are presented for cross-reactions between the three reproductive tissues for any particular absorbed antiserum. The three absorbed antisera produced no antigen-antibody precipitin bands when allowed 
to react with the sixteen non-reproductive tissues or the testis preparations from each of the different species.

\section{Controls}

For controls, the various rabbit and non-rabbit tissues were allowed to react in immunodiffusion plates with sheep and rabbit control sera, PBS and PBS which had been subjected to the $\mathrm{p}-, \mathrm{k}$ - and s-absorption procedure. Neither of the two control sera nor the PBS produced precipitin bands against any of the

Table 4. Reproductive tissue-specific antigens present in different species

\begin{tabular}{l|c|c|c|c|c|c|c}
\hline & \multicolumn{7}{|c}{ Species } \\
\cline { 2 - 7 } & $\begin{array}{c}\text { Reactants } \\
\text { Californian } \\
\text { rabbit }\end{array}$ & $\begin{array}{c}\text { Dutch } \\
\text { rabbit }\end{array}$ & $\begin{array}{c}\text { Zealand } \\
\text { White } \\
\text { rabbit }\end{array}$ & $\begin{array}{c}\text { Guinea- } \\
\text { pig }\end{array}$ & Hamster & Mouse & Rat \\
\hline $\begin{array}{c}\text { Anti-ovary sera* versus } \\
\text { ovary }\end{array}$ & 2 & 2 & 2 & 0 & 0 & 0 & 0 \\
$\begin{array}{c}\text { Anti-oviduct sera* versus } \\
\text { oviduct }\end{array}$ & 6 & 6 & 6 & 0 & 0 & 2 & 1 \\
$\begin{array}{c}\text { Anti-uterus sera* versus } \\
\text { uterus }\end{array}$ & 2 & 1 & 2 & 1 & 1 & 1 & 1 \\
\hline
\end{tabular}

Numerals represent the numbers of antigen-antibody precipitin bands observed in immunodiffusion plates when the antisera were allowed to react against the homologous reproductive tissue from the different species. Each reaction was tested at least fifteen times and involved the use of different preparations of reactants.

* Prepared in sheep against Californian rabbit reproductive tissue and absorbed with Californian rabbit plasma, kidney and spleen.

reproductive or non-reproductive tissues. Phosphate-buffered saline absorbed with p, k, s did produce 'non-immune precipitin bands' (Niece \& Barrett, 1963) against certain tissues. These non-immune precipitin bands were subtracted from the total number of bands produced by the absorbed antisera.

The antigens represented in Table 4 do not include these non-immune precipitin bands.

\section{DISCUSSION}

The results of this investigation have shown that unabsorbed antisera prepared against Galifornian rabbit ovary, oviduct and uterus expressed a high degree of cross-reactivity for the tissues of the two heterologous breeds of rabbits tested but a low degree of cross-reactivity for homologous tissues of the guinea-pig, hamster, mouse and rat. The numbers of precipitin bands observed between the antisera and any particular rabbit tissue were similar, indicating the presence of common antigens in homologous tissues of the three breeds of rabbit. In some instances, however, more precipitin bands were observed against a tissue of the heterologous breed rather than against the corresponding Californian tissue. It has been established in a previous paper (Sacco \& Shivers, 1973a) that many of the precipitin bands produced by the unabsorbed antisera actually consist of families of bands, i.e. several antigen-antibody complexes present in the same region of the gel and appearing as a single band. Consequently, the number of 
precipitin bands observed between an antiserum and a tissue extract indicated only the minimum number of precipitating antigen-antibody complexes. If all antigen-antibody complexes present in the immunodiffusion plates could be distinguished, there would probably be a much closer correlation in band numbers produced against any one type of rabbit tissue.

The occurrence of non-immune precipitation in immunodiffusion tests involving tissue extracts has been reported (Berenbaum, Kitch \& Cope, 1962; Niece \& Barrett, 1963; Clausen, 1969). Such non-immune precipitin bands are probably due to lipid, lipoprotein or lipopolysaccharide components of low water solubility or to enzyme components (Clausen, 1969). All the antigenic preparations used in the present investigation as well as the p-, k- and sabsorbed antisera and controls would include these types of components.

The low degree of cross-reactivity displayed by the unabsorbed antisera for the heterologous tissues was not unexpected. Electrophoretic analysis has shown (Deutsch \& Goodloe, 1945; Moore, 1945) that appreciable and specific characteristic differences occur in the distribution and relative proportions of blood proteins among different species of animals. Furthermore, immunological data indicate that the occurrence and intensity of cross-reactions among antigens from different species parallel the degree of zoological relationship between the species (Kabat \& Mayer, 1964). Consequently, less cross-reactivity would be expected between a particular antiserum and tissues from different species as compared to tissues from the homologous species. However, the observation that antigen-antibody precipitin bands were produced in reactions involving plasma-, kidney- and spleen-absorbed antisera and several of the reproductive tissues from the non-rabbit species is of interest. Such bands were interpreted as indicating the presence of antigens specific to these reproductive tissues since the absorbed antisera did not produce antigen-antibody precipitin bands against any non-reproductive tissue tested. If these tissue-specific antigens are involved in reproductive processes, then antisera prepared against these antigens might be useful in fertility control. Indeed, the results of the present investigation suggest that antisera prepared against tissue-specific antigens in one species may be effectively utilized in tests for controlling fertility in other species.

\section{ACKNOWLEDGMENTS}

This work was supported by a grant (HD 04020) from the National Institute of Child Health and Human Development and by a National Institutes of Health Predoctoral Fellowship (5 F01 GM 46521).

\section{REFERENCES}

Berenbaum, M. G., Krrah, G. M. \& Cope, W. A. (1962) Spurious 'auto-immune' reactions in geldiffusion plates. Nature, Lond. 193, 81.

Clausen, J. (1969) Immunochemical techniques for the identification and estimation of macromolecules. In: Laboratory Techniques in Biochemistry and Molecular Biology, Vol. 1, pp. 419, 499. Eds. T. S. Work and E. Work. American Elsevier Publishing Co., New York.

Deutsch, H. F. \& Goodloe, M. B. (1945) An electrophoretic survey of various animal plasmas. $\mathcal{J}$. biol. Chem. 161, 1. 
KABAT, E. A. \& MAYer, M. M. (1964) Experimental immunochemistry, 2nd edn, p. 22. Charles G. Thomas, Springfield, Illinois.

MANSI, W. (1958) Slide gel diffusion precipitin test. Nature, Lond. 181, 1289.

MooRe, D. H. (1945) Species differences in serum protein patterns. F. biol. Chem. 161, 21.

NiECE, J. L. \& BARRETT, J. T. (1963) Non-immune gel precipitin tests with an enzyme antigen. Nature, Lond. 197, 1021.

SAcco, A. G. \& Shrvers, C. A. (1973a) Antigens of the rabbit ovary, oviduct and uterus. F. Reprod. Fert. 32, 403.

SAcco, A. G. \& Shrvers, G. A. (1973b) Localization of tissue-specific antigens in the rabbit ovary, oviduct and uterus by the fluorescent antibody technique. F. Reprod. Fert. 32, 415. 